\title{
The perception of corn farmers about biological control of Caradrina by Braconid in Dezful Township, Khouzestan Province, Iran
}

\author{
Ahmad Reza Ommani* \\ Department of Agricultural Management, Shoushtar Branch, Islamic Azad University, Shoushtar, Iran. \\ E-mail: a.omani@iau-shoushtar.ac.ir. Tel: 00986114457786. Fax: 00986114439062. \\ Accepted 15 June, 2011
}

\begin{abstract}
The purpose of this study was to analyze the perception of corn farmers about biological control of Caradrina by Braconid in Dezful Township, Khouzestan Province, Iran. The method used in this study was correlative descriptive and causal relation. A random sample of Dezful township corn farmers of Khouzestan Province, Iran $(n=350)$ was selected for participation in this study. A questionnaire was developed to gather information regarding perception of farmers on biological control of Caradrina by Braconid in corn farms of Dezful Township, Khouzestan Province. The questionnaire was pilot tested in Shoushtar Township, Khouzestan Province. Questionnaire reliability was estimated by calculating Cronbach's alpha. Reliability was Cronbach's alpha $=0.85$. Data collected were analyzed using the Statistical Package for the Social Sciences (SPSS). According to results of this study, there were significant correlation between perception of corn farmers about biological control of Caradrina by Braconid with work experience, social participation, level of education, income, technical knowledge and extension activity. The result of regression indicates that $38 \%$ of the variances in the perception of respondents could be explained by the social participation, level of education, income, technical knowledge and extension activity.
\end{abstract}

Key words: Biological control, Caradrina, Braconid, corn farmers, Dezful.

\section{INTRODUCTION}

Fundamental contributor to the Green Revolution has been the development and application of pesticides for the control of a wide variety of insectivorous and herbaceous pests that would otherwise diminish the quantity and quality of food produced. The use of pesticides coincides with the "chemical age" which has transformed society since the 1950s. In areas where intensive monoculture is practiced, pesticides were used as a standard method for pest control. Unfortunately, with the benefits of chemistry, there have also come 'disbenefits', some so serious that they now threaten the long-term survival of major ecosystems by disruption of predatorprey relationships and loss of biodiversity. Also, pesticides can have significant human health consequences (FAO, 2003). Chemical control of insect pests is the most dominant approach at present. It is responsible for many health hazards among people and livestock. Evidences of pesticide threats to human health and economic effects have been documented in several studies (Singh et al,
2008). However, it is evident, more than any time, that there is need for application of new technologies in the agricultural sector (Hosseini et al, 2010). Biological control, as new technology, is the use of one or more types of beneficial organisms, to reduce the numbers of another type of organism (Mahr et al, 2001). Also, it has been defined as "the intentional use by humans of parasitoid, predator, pathogen, antagonist, or competitor populations to suppress a pest population, thereby making the pest less abundant and damaging than it would be in the absence of these organisms" (Hoddle, 2004). Through biological control, it has been estimated that pests reduce global crop yields by $42 \%$ annually; pest management using biological methods is believed to provide $60 \%$ of the non-chemical control of these pests (Pimentel et al., 1997). Biological control is often divided into three categories. All of these can be part of an integrated pest management program. The three categories are: classical biological control, augmentative bio- 


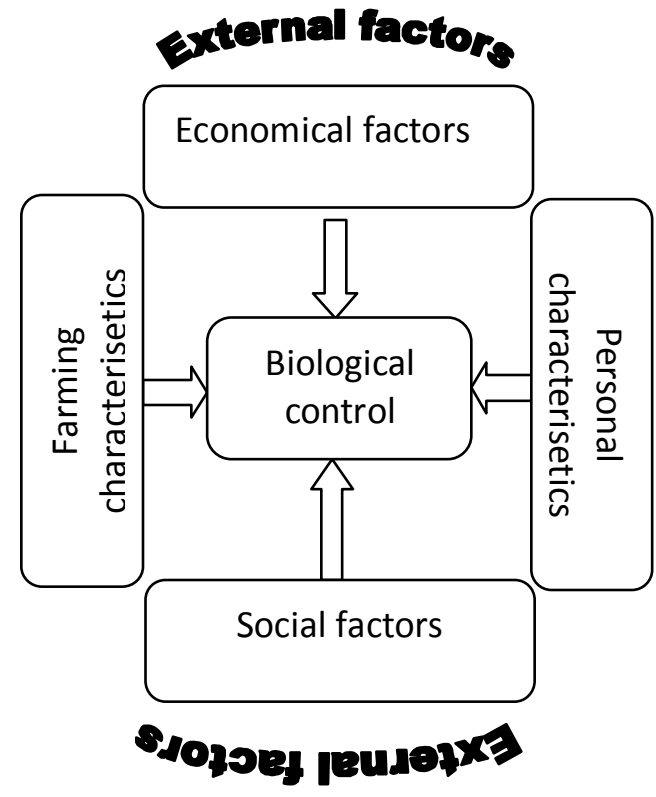

Figure 1. Theoretical framework.

logical control and conservation biological control. Abeydeera (1994) reported that biological control application decreases total control cost more than where no biological agent is used.

This study presents a single case study on effective social factors of adoption of biological control by rice farmer in north of Iran. According to Niyaki et al. (2010), the main important factors of adoption of biological control include education level, family size, experience in rice culture, rate of participation in educationalextensional activities.

The Braconid constitutes one of the most species-rich families of insects (Whitfield et al., 2004; Quicke et al., 1999). The majority of Braconid is parasitoids of other insects. They almost invariably kill their hosts, although, a few only cause their hosts to become sterile and less active. Both external and internal parasitoids are common in the family, and the latter forms often display elaborate physiological adaptations for enhancement of larval survival within host insects, including the co-option of end symbiotic viruses for compromising host immune defenses (Whitfield, 2002; Whitfield and Asgari, 2003; Whitfield et al., 2004).

One of the insects that were parasitized by Braconid is Caradrina. Caradrina attack various plants such as sugar beet, alfalfa and corn.

The purpose of this study was to analyze the perception of corn farmers on biological control of Caradrina by Braconid in Dezful Township, Khouzestan Province, Iran.

\section{MATERIALS AND METHODS}

The method used in this study was correlative descriptive and causal relation. A random sample of Dezful township corn farmers of Khouzestan province, Iran $(\mathrm{n}=350)$ was selected for participation in this study. A questionnaire was developed to gather information regarding perception of corn farmers regarding biological control of Caradrina by Braconid in Dezful township of Khouzestan Province. The questionnaire was piloted and tested in Shoushtar Township. Questionnaire reliability was estimated by calculating Cronbach's alpha. Reliability was Cronbach's alpha = 0.85 . Data collected were analyzed using the Statistical Package for the Social Sciences (SPSS). Appropriate statistical procedures for description (frequencies, percent, means and standard deviations) were used. This study was carried out by survey during July and August 2010 (Figure 1).

\section{RESULTS \\ Demographic profile}

The first section described farmers' demographic profile in Dezful Township, Khuzestan Province of Iran. As seen in Table 1, approximately, $56 \%$ of respondents were between 36 to 50 years of age and $31.7 \%$ of them between 22 to 35 years of age (Table 1). Most respondents (46.6\%) reported work experience, including 1 to 15 years and the vast majority of them were male (89.04\%).

In reference to the frequency of respondents' social participation, $64 \%$ of farmers had moderate level. About $32 \%$ of corn farmers had reached primary school level. Based on the results of this study, the incomes of $68.9 \%$ of corn farmers were between ten million to one hundred million Rials in a year (Table 1 and Figure 2).

\section{Perception of corn farmers on biological control of Caradrina by Braconid}

In finding the perception of respondents and their attitudes towards biological control of Caradrina by Braconid, they were asked to give their perceptions of items of biological control on a five Likert scale $(1=$ strongly disagree, 2 = disagree, $3=$ unsure, $4=$ agree, 5 $=$ strongly agree). Their answers to these items in combination led to their perceptions of biological control of Caradrina by Braconid. As can be seen, the highest mean number refers to the role of biological control in conservation of natural resources (mean $=2.911)$. As seen in Table 2, approximately, $40.6 \%$ of respondents agreed with role of biological control in conservation of natural resources (Table 2).

\section{Correlation study}

Spearman coefficient was employed for measurement of relationships between independent variables and dependent variable. Table 3 displays the results which showed that there is a relationship between perception of 
Table 1. Personal, social and economical characteristics of corn farmers.

\begin{tabular}{|c|c|c|c|}
\hline Characteristic & Frequency & Percent & Cumulative percent \\
\hline \multicolumn{4}{|l|}{ Age } \\
\hline $20-35$ & 111 & 31.7 & 31.7 \\
\hline $36-50$ & 196 & 56 & 87.7 \\
\hline $51-65$ & 40 & 11.4 & 99.1 \\
\hline $66-80$ & 3 & 0.9 & 100 \\
\hline \multicolumn{4}{|l|}{ Work experience } \\
\hline $1-15$ & 163 & 46.6 & 46.6 \\
\hline $16-30$ & 159 & 45.4 & 92 \\
\hline $31-45$ & 26 & 7.4 & 99.4 \\
\hline $46-60$ & 2 & 0.6 & 100 \\
\hline \multicolumn{4}{|c|}{ Social participation } \\
\hline Low & 67 & 19.1 & 19.1 \\
\hline Moderate & 224 & 64 & 83.1 \\
\hline High & 59 & 16.9 & 100 \\
\hline \multicolumn{4}{|l|}{ Level of education } \\
\hline Uneducated & 40 & 11.4 & 11.4 \\
\hline Primary school & 114 & 32.6 & 44 \\
\hline Secondary school & 106 & 30.3 & 74.3 \\
\hline High school & 90 & 25.7 & 100 \\
\hline \multicolumn{4}{|c|}{ Income (Million Rials) } \\
\hline $10-100$ & 241 & 68.9 & 68.9 \\
\hline $100-200$ & 79 & 22.6 & 91.4 \\
\hline $200-300$ & 18 & 5.1 & 96.6 \\
\hline $300-400$ & 9 & 2.6 & 99.1 \\
\hline $400-500$ & 3 & 0.9 & 100 \\
\hline
\end{tabular}

corn farmers on biological control of Caradrina by Braconid as dependent variable and personal, social and economical characteristics as independent variables.

Based on the results there is significant correlation between perception of corn farmers on biological control of Caradrina by Braconid with work experience, social participation, level of education, income, technical knowledge and extension activity.

\section{Regression analysis}

Table 4 shows the result for regression analysis by stepwise method. Independent variables that were signifi- cantly related to the perception of corn farmers on biological control of Caradrina by Braconid were entered. The result indicates that $38 \%$ of the variances in the perception of respondents could be explained by the social participation, level of education, income, technical knowledge and extension activity.

\section{DISCUSSION}

According to the results of this study, there is significant correlation between perception of corn farmers on biological control of Caradrina by Braconid with work experience, social participation, level of education, income 


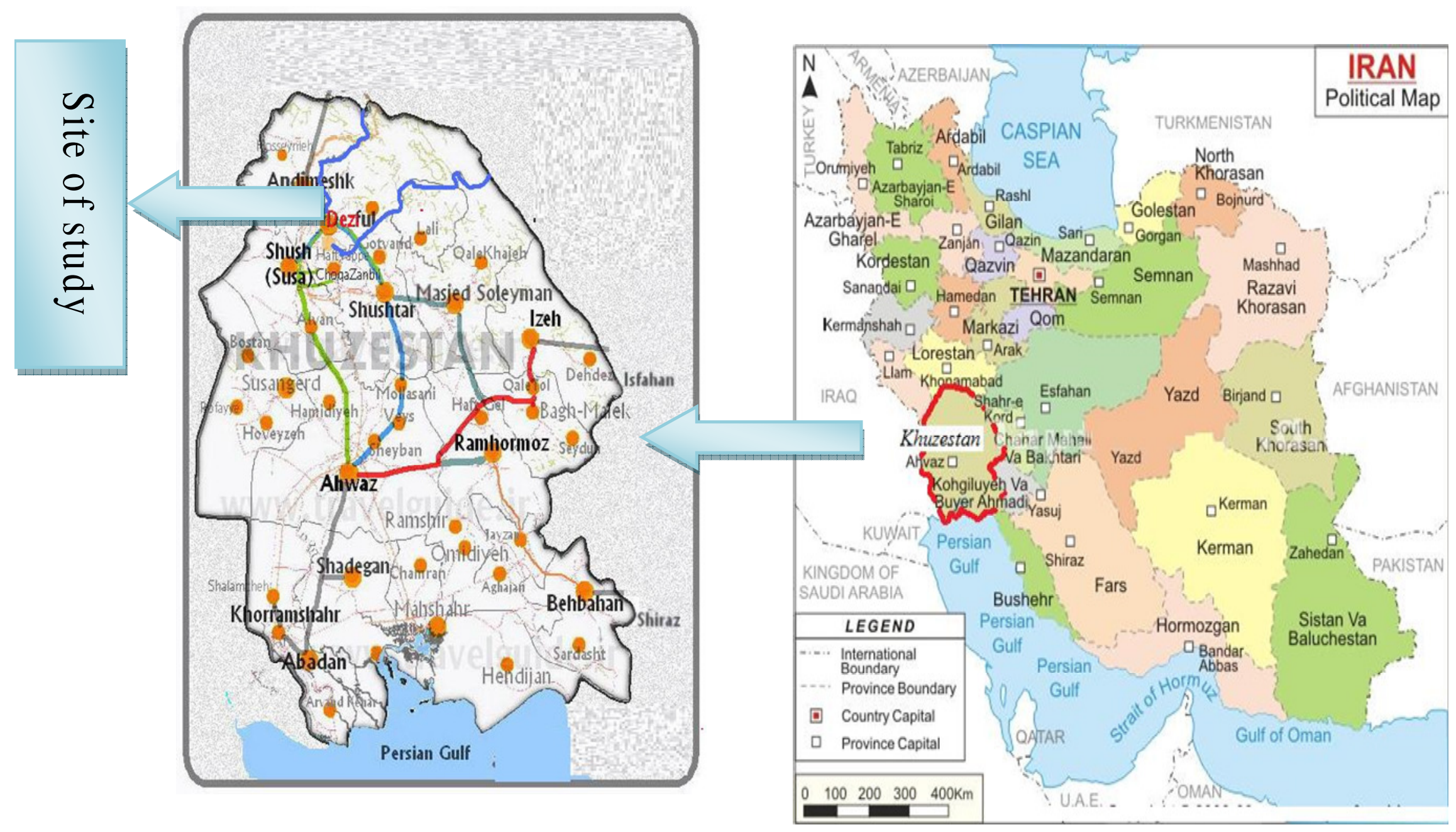

Figure 2. Site of study in south of Iran.

income, technical knowledge and extension activity.

According to Niyaki et al. (2010), the main important factors of adoption of biological control include education level, family size, experience in rice culture, rate of participation in educationalextensional activities. Singh et al. (2008) have shown that technology awareness through formal crop-specific IPM training provided by farmers' field schools is extremely important for wider adoption of IPM in the study area. Hence, investment in IPM education through these programs will have long-term beneficial impact.

Based on the results, $43 \%$ of respondents agreed with the role of biological control in 
Table 2. Perception of corn farmers about biological control of Caradrina by Braconid.

\begin{tabular}{|c|c|c|c|c|c|c|c|c|c|c|c|c|}
\hline \multirow{2}{*}{ Dimension } & \multicolumn{2}{|c|}{1} & \multicolumn{2}{|c|}{2} & \multicolumn{2}{|c|}{3} & \multicolumn{2}{|c|}{4} & \multicolumn{2}{|c|}{0} & \multirow{2}{*}{ Mean } & \multirow{2}{*}{ sd } \\
\hline & $f$ & $\%$ & $f$ & $\%$ & $f$ & $\%$ & $f$ & $\%$ & $f$ & $\%$ & & \\
\hline Reduce dependency to pesticides & 6 & 1.7 & 38 & 10.9 & 53 & 15.1 & 180 & 51.4 & 73 & 20.9 & 2.788 & 0.952 \\
\hline Increase quality of crops & 6 & 1.7 & 46 & 13.1 & 49 & 14 & 158 & 45.1 & 91 & 26 & 2.805 & 1.022 \\
\hline Increase crop yield in long time & 3 & 0.9 & 54 & 15.4 & 6 & 18.9 & 151 & 43.1 & 76 & 21.7 & 2.694 & 1.004 \\
\hline Conservation of natural resources & 10 & 2.9 & 47 & 13.4 & 29 & 8.3 & 142 & 40.6 & 122 & 34.9 & 2.911 & 0.379 \\
\hline It is economically feasible & 23 & 6.6 & 73 & 20.8 & 45 & 12.9 & 116 & 33.1 & 93 & 26.6 & 2.522 & 1.263 \\
\hline It is socially acceptable & 9 & 2.6 & 66 & 18.9 & 67 & 19.1 & 140 & 40 & 68 & 19.4 & 2.548 & 1.082 \\
\hline
\end{tabular}

1 = Strongly disagree, 2 = disagree, 3 = unsure, 4 = agree, 5 = strongly agree. Sd, standard deviation.

Table 3. Correlation measures between independent variables and perception of corn farmers about biological control of Caradrina by Braconid.

\begin{tabular}{lcc}
\hline Variable 1 & $\mathbf{r}$ & $\mathbf{p}$ \\
\hline Age & 0.019 & 0.632 \\
Work experience & $0.032^{* *}$ & 0.541 \\
Social Participation & $0.312^{* *}$ & 0.000 \\
Level of education & $0.412^{* *}$ & 0.000 \\
Income & $0.378^{\star *}$ & 0.000 \\
Technical knowledge & $0.416^{* *}$ & 0.000 \\
Extension activity & $0.451^{* *}$ & 0.000 \\
\hline
\end{tabular}

Variable 1: Perception of corn farmers about biological control of Caradrina by Braconid. ${ }^{*} \mathrm{p}<0.05 ;{ }^{* *} \mathrm{p}<0.01$.

Table 4. Multivariate regression analysis.

\begin{tabular}{lcccc}
\hline $\begin{array}{l}\text { Multivariate regression } \\
\text { analysis }\end{array}$ & B & Beta & T & Significance \\
\hline Constant & 2.564 & ------ & 4.329 & 0.000 \\
Technical knowledge & 0.171 & 0.198 & 2.769 & 0.000 \\
Social Participation & 0.341 & 0.319 & 2.731 & 0.000 \\
Level of education & 0.193 & 0.338 & 3.901 & 0.000 \\
Income & 0.213 & 0.561 & 3.908 & 0.000 \\
Extension activity & 0.301 & 0.490 & 2.009 & 0.000 \\
\hline
\end{tabular}

$R^{2}=0.381, Y=2.561+0.171 X_{1}+0.341 X_{2}+0.193 X_{3}+0.213 X_{4}+0.301 X_{5}$

increasing crop yield for a long time. Hoddle (2004) noted that farmers may adopt biological control practices if they result in reduced costs for agrichemicals, labor and specialized equipment.

According to the results, $60 \%$ of respondents agreed that biological control is economically feasible. Cullen et al (2008) noted that farmers must perceive biological pest control innovations to have economic advantages at an acceptable level of risk when compared to the relatively simple conventional agrichemical control methods. Thekey finding of this study is that biological control innovations must be developed in a manner which gives consideration to the realities at the farm level.

Based on the results, farmers have a favorable attitude toward biological control of the pest. According to the obtained relationship between variables, extension and education classes should be in the field of biological control to be held. Emphasis on training needs must be considered. Necessary background to develop technical knowledge and skills of farmers should be provided. Considering the devastating impact of chemical pesticides and due to favorable attitudes towards biological control, there have been a wide efforts in its dissemination in order to provide healthy living conditions. 


\section{REFERENCES}

Abeydeera WM (1994). Impact of intervention: integrated pest management in rice based farming system. Paper presented of the third Asia farming systems symposium. (From Agris abstract).

Cullen R, Warner KD, Jonsson M, Wratten SD (2008). Economics and adoption ofconservation biological control. Biol. Control. 45: 272-280.

FAO (2003). Sustainable Water Resources Management for Food Security in the Near East Region. High-Level Technical Workshop "Regional Programs for Food Security in the Near East: Towards Sustainable Food Security and Poverty Alleviation", Jeddah, 8-9 October 2003, FAO.

Hoddle MS (2004). Restoring balance: Usingexotic species to control invasive exotic species. Conservation Biol. 18(1): 38-49.

Hosseini JF, Dehyouri S, Mirdamadi M (2010). The perception of Agricultural Researchers about the Role of Nanotechnology in Achieving Food Security. Afr. J. Biotechnol. 9(37): 6152-6157.

Mahr SER, Cloyd RA, Mahr DL, Sadof CS (2001). Biological control of insects and other pests of greenhouse crops. Univ. of WisconsinExtension, Cooperative Extension.

Niyaki AL, Radjabi R, Allahyari MS (2010). Social Factors Critical for Adoption of Biological Control Agents Trichogramma Spp. Egg Parasitoid of Rice Stem Borer Chilo suppressalis in North of Iran. Amr.-Eurasian J. Agric. Environ. Sci. 9(2): 133-139.

Pimentel D, Wilson C, McCullum C, Huang R, Dwen P, Flack J, Tran Q, Saltman T, Cliff B (1997). Economic and environmental benefits of biodiversity. BioSci. 47(11): 747-757.
Quicke DLJ, Basibuyk HH, Fitton MG, Rasnitsyn AP (1999). Morphological, paleontological and molecular aspects of ichneumonoid phylogeny (Hymenoptera, Insecta). Zool. Script. 28: 175-202.

Singh A, Vasishtb AK, Kumara R, Dasc DK (2008). Adoption of Integrated Pest Management Practices in Paddy and Cotton: A Case Study in Haryana and Punjab. Agric. Econ. Res. Rev. JulyDecember 2008 21: 221-226.

Whitfield JB (2002). Estimating the age of the polydnavirus/braconid wasp symbiosis. Proc. Natl. Acad. Sci. USA., 99: 7508-7513.

Whitfield JB, Asgari S (2003). Virus or not? phylogenetics of polydnaviruses and their wasp carriers. J. Inst. Physiol. 49: 397-405.

Whitfield JB, Won-Young C, Alejandro AV, Josephine R, Andrew RD (2004). Braconid. Version 10 June 2004. http://tolweb.org/Braconid/23447/2004.06.10in The Tree of Life Web Project, http://tolweb.org/ 